\title{
Geothermal Energy Development in Indonesia: Progress, Challenges and Prospect
}

\author{
Hadi Setiawan \\ Fiscal Policy Office, Ministry of Finance, Republic of Indonesia, Jalan Wahidin Raya No. 1, Jakarta Pusat, 10710, Indonesia \\ E-mail: hsetiawan@fiskal.depkeu.go.id
}

\begin{abstract}
One of environmental friendly renewable energies with huge potential in Indonesia is geothermal. Indonesia has the largest geothermal potential in the world, reaching up to $40 \%$ of world reserves or about $27,000 \mathrm{MW}$ to $29,000 \mathrm{MW}$. However the development of geothermal currently is only about $4.2 \%(1,226 \mathrm{MW})$ of the existing reserves. The government of Indonesia has issued both fiscal and non-fiscal incentives to encourage geothermal development including establishing Fast Track Program II in 2010 to procure $17,918 \mathrm{MW}$ of which $28 \%$ of them are geothermal. But apparently the amount of electricity that can be supplied from geothermal is only about $2.7 \%$ of total installed generations in Indonesia. This paper presents the progress of geothermal development in Indonesia and the role of the government including the policy, regulatory framework, and government incentives. It also identifies the challenges of the geothermal development, as well as its prospects in the future. Methodology used in this research is qualitative-descriptive method focused on literature review to obtain literature or secondary data.
\end{abstract}

Keywords - Geothermal; electricity; government role.

\section{INTRODUCTION}

Though electricity plays important role in national development, Indonesian electrification ratio only reached $75.9 \%$ in 2012 [1], far behind compared to countries in the region, e.g. Singapore $100 \%$, Malaysia $99.4 \%$, even Philippine and Vietnam, which each have $89.7 \%$ and $87 \%$ [2]. Right now Indonesia is approaching to the electricity crisis. Some areas already lack of electricity such as North Sumatera, Aceh, Papua, and others. Even Java would also be predicted to the electricity crisis in 2016 if there is no fundamental action from government [3].

In Indonesia, the elasticity of electricity to the national development ranged between 1-2 percent, with an average of 1.286 in the last 10 years [4]. This means that any $1 \%$ increase in growth, there will be electricity increases by 1.286 times. Therefore, the demand for electricity will increase in line with rising economic growth. Especially at this time when Indonesia has imposed a ban on the export of raw minerals, which means, it takes a lot of smelters that requires electricity in the amount of stout [2]. In addition, electricity consumption per capita in Indonesia is also much lower than countries in the region [5] which means productivity of Indonesia's population is not utilized optimally.
The Indonesian government is very concerned about this, since if electricity growth is just like business as usual, then Indonesia will experience severe power crisis. Therefore, in MP3EI, electricity dominates the overall infrastructure projects planned, amounting to $39 \%$ or Rp669 trillion [6]. PLN, as the sole provider of electricity in Indonesia has also planned to make electrification ratio reach $97.7 \%$ in 2022 [1]. One of the efforts made by the Indonesian government is developing renewable energy such as geothermal energy, solar energy, wind energy, and biomass energy to answer the growing energy demand and also solving climate change problem.

To achieve this, the Government of Indonesia (GoI) has issued both fiscal and non-fiscal incentives such as Fast Track Program (FTP) I in 2006 and FTP II in $2010^{1}$. Especially for FTP II, the sources of energy used are specific of renewable energy, gas and coal (Table I) [7]. The government determined that the geothermal portion of the FTP II is $28 \%$ of all plants or at $4,965 \mathrm{MW}$.

This target is very possible since Indonesia has the largest of geothermal potential in the world, reaching up to $40 \%$ of world reserves or about 27,000 MW to 29,000 MW. While the development of geothermal is only at about $4 \%(1,226$

\footnotetext{
${ }^{1}$ Fast Track Program is a program of the government to accelarate the development of generations by giving a guarantee to investors or lenders
} 
MW) of existing reserves [8] or only 3\% of the total installed generation in Indonesia [1]. So the number of 4,965 MW is still a small fraction of geothermal potential in Indonesia, compared to Philippines that already using geothermal approximately $27 \%$ of the country's electricity generation [9].

TABLE I

LIST PROJECT FTP II

\begin{tabular}{|c|c|c|c|}
\hline Developer & $\begin{array}{c}\text { Type of } \\
\text { Generators }\end{array}$ & $\begin{array}{c}\text { No of } \\
\text { Project }\end{array}$ & $\begin{array}{c}\text { Capacity } \\
\text { (MW) }\end{array}$ \\
\hline & Geothermal & 6 & 340 \\
\hline $\begin{array}{l}\text { PLN } \\
17 \text { Proiects }\end{array}$ & Water & 4 & 1,379 \\
\hline $5749 \mathrm{MW}(32 \%)$ & Coal & 6 & 3,750 \\
\hline & Gas & 1 & 280 \\
\hline IPP & Geothermal & 46 & 4,625 \\
\hline 59 Projects & Water & 6 & 424 \\
\hline $12,169 \mathrm{MW}(68 \%)$ & Coal & 7 & 7,120 \\
\hline Total & & 76 & 17,918 \\
\hline
\end{tabular}

Source: Minister MEMR Decree No 21/2013

This paper presents the progress of geothermal development in Indonesia and the role of the government including the policy, regulatory framework, and government incentives. It also identifies the bottlenecks or challenges of the geothermal development, and more importantly its prospects in the future.

\section{METHODOLOGY}

This research uses qualitative-descriptive method focused on literature review to obtain literature or secondary data. The data used are secondary data obtained from various sources, such as, Ministry of Energy and Mineral Resources (MEMR), Ministry of Finance, PT PLN as well as a range of research and other resources accessed through the internet.

\section{GEOTHERMAL ENERGY DEVELOPMENT PROGRESS}

\section{A. Geothermal Energy Development}

Geothermal development in Indonesia can be divided into three regimes, namely (i) Pre-Law No. 27 of 2003 about Geothermal (Geothermal Law); (ii) Era of Geothermal Law [10]; and Post-Geothermal Law. The Post Geothermal Law Era will be discussed in the next section.

\section{1) Pre Geothermal Law Era}

The first drilling of geothermal is conducted in 1926 at Kamojang, West Java. More aggressive activities being done in 1970s with the issuance of Presidential Decree No. $16 / 1974$, which required Pertamina to conduct survey and exploration in Java Bali, while outside Java Bali conduct by the Government. The drillings that have been done in this era, including in Kamojang, Dieng (by Pertamina), and Lahendong (by government). Then Presidential Decree No. 22 of 1981 isssued which gives monopoly rights to Pertamina to conduct a survey, exploration and exploitation of geothermal energy in Indonesia. According to this rule, Pertamina must sell geothermal steam to PLN.

In 1983, the first geothermal power plant operating in Indonesia precisely in Kamojang with a capacity of $30 \mathrm{MW}$, followed by the second and third units of 2 x $55 \mathrm{MW}$ in 1988 [8]. While in 1982, Pertamina formed a partnership with Unocal Geothermal Indonesia in Mount Cisalak hotspot and operated in 1994 for Unit I and II. Pertamina also made cooperation with Amoseas in 1984 in Darajat and operates also in 1994 [10].

In 1991 the government issued Decree 45/1991 as an improvement of the Presidential Decree 22/1981 which provided more flexibility to Pertamina along with the contractor to develop geothermal energy in Indonesia and then sell it either in the form of steam or electricity to PLN. 1990s was the golden era of geothermal in Indonesia, which is marked by the large number who signed a Joint Operation Contract, including Unocal North Sumatera Geothermal (Sarulla, 1993), Himpurna California Energy (Dieng, 1994), Karaha Bodas Company (Karaha, 1994), Mandala Magma Nusantara (Wayang Windu, 1994), Patuha Power (Patuha, 1994), and Bali Energy (Bedugul, 1995). In the 1990s also marked by the operation of Lahendong, Wayang Windu and Sibayak geothermal power plants [10].

At the beginning of 2000 through Presidential Decree No. $76 / 2000$, Pertamina's monopoly rights on Geothermal repealed and every business can be sought in the field of geothermal energy.

\section{2) Geothermal Law Era}

In 2003 GoI issued Geothermal Law that changed the regime of geothermal management in Indonesia. This law strengthens the Presidential Decree 76/2000 which provided more flexibility to all businesses to strive in the field of geothermal energy through an auction process before getting Geothermal Mining Permit (IUP=Ijin Usaha Pertambangan). In addition, this Law authorizes local government to have an active role and opportunities to issue permits, guidance and supervision to manage geothermal resources (the spirit of regional autonomy). The Law also gives powers to the Central Government and Local Government do the preliminary survey to exploration drilling [11]. The data obtained is then used as the basis for setting Geothermal Working Area (GWA). This GWA then used in the auction by either the Central Government or Local Government [10].

After the enactment of Geothermal Law, Government has issued 35 GWA, while earlier this law, government issued as much as 19 GWA. Total GWA issued by the Government till now are 54 GWA of the total 276 geothermal hotspots. And there are 7 of the 54 GWA were already in production (Table II) and those all are issued before the Geothermal Law [8]. While the reserved of the new GWA (35 GWA issued after Geothermal Law) are 4,100 MW and all are not produced yet [12].

The GoI planned to add as much as 3,516 MW of installed capacity by 2015 (Table III) [12]. While Minister MEMR Decree number 15/2010 as amended by the Minister MEMR Decree number 21/2013 which is a translation of FTP II targets to increase the installed capacity of geothermal power plants as much as 4,965 MW to 2024 in 52 projects. All 52 projects are referred to as FTP II projects.

The GoI also released the roadmap of energy Indonesia in the Presidential Decree No 5/2006. This rule mandates that the Indonesian energy sources come from renewable energy are $17 \%$ by 2025 , which mostly comes from geothermal [13]. But so far it does not go according to the plan. It is 
proved by the geothermal power plants remain at 1,226 MW from year 2011 until now.

TABLE II

LiST OF GEOTHERMAL POWER Plants

\begin{tabular}{|c|c|c|c|c|c|}
\hline $\begin{array}{l}\mathbf{N} \\
\mathbf{o}\end{array}$ & GWA & $\begin{array}{l}\text { License } \\
\text { Holder }\end{array}$ & Developer & $\begin{array}{c}\text { Power } \\
\text { Plant }\end{array}$ & $\begin{array}{c}\text { Capacity } \\
\text { (MW) }\end{array}$ \\
\hline 1 & $\begin{array}{l}\text { Sibayak- } \\
\text { Sinabung }\end{array}$ & $\begin{array}{l}\text { Pertamina } \\
\text { Geothermal } \\
\text { Energy } \\
\text { (PGE) }\end{array}$ & PGE & Sibayak & 12 \\
\hline 2 & $\begin{array}{l}\text { Cibeuruem - } \\
\text { Parabakti }\end{array}$ & PGE & $\begin{array}{l}\text { Chevron } \\
\text { Gheother mal } \\
\text { Indonesia }\end{array}$ & Salak & 337 \\
\hline 3 & Pengalengan & PGE & Star Energy & $\begin{array}{l}\text { Wayang } \\
\text { Windu }\end{array}$ & 227 \\
\hline 4 & $\begin{array}{l}\text { Kamojang - } \\
\text { Darajat }\end{array}$ & PGE & PGE & Kamojang & 200 \\
\hline 5 & $\begin{array}{l}\text { Kamojang - } \\
\text { Darajat }\end{array}$ & PGE & $\begin{array}{l}\text { Chevron } \\
\text { Geothermal } \\
\text { Indonesia }\end{array}$ & Darajat & 270 \\
\hline 6 & Dieng & PGE & $\begin{array}{l}\text { Geo Dipa } \\
\text { Energy }\end{array}$ & Dieng & 60 \\
\hline 7 & $\begin{array}{l}\text { Lahendong - } \\
\text { Tompaso }\end{array}$ & PGE & PGE & Lahendong & 80 \\
\hline & TOTAL & & & & 1,226 \\
\hline
\end{tabular}

Source: Remigius, 2012

TABLE III

GeOTHERMAL DEVELOPMENT PLAN AND REALIZATION $2010-2015$

\begin{tabular}{|c|c|c|c|c|c|c|}
\hline $\begin{array}{c}\text { Develop } \\
\text { ment }\end{array}$ & '10 & '11 & '12 & '13 & '14 & '15 \\
\hline $\begin{array}{l}\text { Adding } \\
\text { capacity }\end{array}$ & 0 & 37 & 115 & 3 & 375 & 1,797 \\
\hline $\begin{array}{c}\text { Installed } \\
\text { Capacity } \\
\text { Investment }\end{array}$ & 1,189 & 1,226 & 1,341 & 1,344 & 1,719 & 3,516 \\
\hline $\begin{array}{l}\text { Assumption } \\
\text { (M USD) }\end{array}$ & & & 402 & 10 & 1,312 & 6,289 \\
\hline
\end{tabular}

\section{B. Fiscal Policy in Geothermal}

Income Tax Regulations on Geothermal in Indonesia since 1981 up to 2010 can be seen in Table IV.

TABEL IV

INCOME TAX REGULATION RELATED TO GEOTHERMAL

\begin{tabular}{lllll}
\multicolumn{5}{c}{ INCOME TAX REGULATION RELATED TO GEOTHERMAL } \\
\hline \multirow{2}{*}{ Element } & KMK & KMK No. & Law No. & PMK No. \\
& No.746/1981 & $\mathbf{7 6 6 / 1 9 9 2}$ & $\mathbf{1 7 / 2 0 0 0}$ & $\mathbf{2 1 / 2 0 1 0}$ \\
\hline Tariff & $46 \%$ & $34 \%$ & $30 \%$ & $25 \%$ \\
Investment & 5\% per year & No & Max & 5\% per year \\
Tax Credit & for 4 years & & $30 \%$ & for 6 year \\
& 6 years & & Straight & \\
& (12.5\% per & Declining & method & Accelerate \\
Depreciation & year except & balance for & or & of \\
& 3rd year & 7 years & declining & depreciation \\
& $37.5 \%$ & & balance & \\
Loss carry & No & 5 years & 5 years & Maks 10 \\
forward & No & No & yes & No \\
Import Tax & No & & & \\
\hline
\end{tabular}

Source: Sukhyar and Danar, 2010

In addition, in 2011, the geothermal business is included in the types of industry which gets the tax holiday as long as it meets certain requirements. These requirements are:

- Investments made at least 1 trillion rupiah;

- Placing funds in Indonesian banks at least $10 \%$ of the investments made;

- Status of the company is Indonesian legal entity [14].
Geothermal investors who meet these requirements will get exemption of income tax for minimum 5 years and maximum 10 years from the commencement of commercial production. Moreover, the investors will also get a reduction of $50 \%$ tariff for 2 years after the income tax exemption period expires.

Those rules as in Table IV apply to the other types of tax. Prior to 1992 there is no VAT. But after Minister of Finance Decree (KMK) No 766/1992 issued then the VAT is imposed, but it can be delayed and refunded. The import duties are also exempted. Beginning in 2000, the VAT is imposed and as well as import duties. But from 2010 and so on, the VAT for geothermal industry are not imposed and import duties back to being exempted [10].

Other than taxation, GoI also provides facilities to the geothermal industry in the form of guaranty as stipulated in Minister of Finance Decree No. 139/2011. Government Guarantee given to geothermal projects which are included in the FTP II. Guaranty is in the form of assurance on the feasibility of PLN to buy electricity from the independent power producer (IPP) based on the Power Purchase Agreement (PPA). Meanwhile, development projects assigned to PT PLN will be funded through the subsidiary loan agreement (SLA), so it does not require guarantee. Government assurance given in the form of Business Viability Guarantee Letter (BVGL/SJKU) signed by the Minister of Finance addressed to the developer. By giving BVGL, government guarantees the failure of PLN's payment risk and project termination risk. Guarantee is also seen as an attempt to support the achievement of financial close to support the development of power plant projects [15].

GoI also provides funding in the field of exploration through a revolving fund which is often referred as "geothermal fund" as stipulated in the PMK 03/2012. Geothermal fund is used for the provision of data/information as well as loans. For the provision of data /information, this fund is provided to the Regional Governments, so they can provide a complete, valid, and adequate data/information so that the exploration risk can be reduced. This better data/information is then used as basis in the preparation of documents for the auction of GWA in Public Private Partnership (PPP) scheme. The goal is to make the geological risk more measurable and manageable, which could result in obtaining better and affordable electricity tariff as well as make the project become bankable. Whereas in the form of loans, this fund is granted to holders of IUP and/or PT Pertamina Geothermal Energy to do the explorations in order to accelerate the expansion of geothermal power plant project [13].

The amount of geothermal funds is quite large, amounting to Rp1,126 billion in the 2011 budget, and each Rp876.5 billion and Rp1,126 billion in 2012 and 2013 budget. Further these funds given to Indonesia Investment Agency (IIA/PIP) as a revolving fund management institutions. But until now, the geothermal fund amount around Rp3 trillion is still unused.

Fiscal incentives summary for the geothermal industry is shown in Table $\mathrm{V}$.

Although it has so many incentives given by the Government, but geothermal energy development in Indonesia is still stalled. 
TABLE V

FISCAL INCENTIVE FOR GEOTHERMAL INDUSTRY

\begin{tabular}{llccc}
\hline No & \multicolumn{1}{c}{ Incentive } & Exploration & Construction & Operation \\
\hline 1 & $\begin{array}{l}\text { Income tax } \\
\text { facility }\end{array}$ & $\sqrt{ }$ & $\sqrt{ }$ & $\sqrt{ }$ \\
2 & $\begin{array}{l}\text { Import duties } \\
\text { facilities }\end{array}$ & $\sqrt{ }$ & $\sqrt{ }$ & $\sqrt{ }$ \\
3 & VAT facilities & $\sqrt{ }$ & $\sqrt{ }$ & $\sqrt{ }$ \\
4 & $\begin{array}{l}\text { Exploration } \\
\text { financing } \\
\text { Guarantee of }\end{array}$ & $\sqrt{ }$ & - & - \\
5 & PLN feasibility & - & - & $\sqrt{ }$ \\
\hline
\end{tabular}

Source: H. Setiawan and S. A, Damayanty., 2012

\section{CHALlENGES OF GEOTHERMAL ENERGY DEVELOPMENT}

There are a lot of challenges/problems in geothermal energy development. These divided into three categories, which are: (i) upstream side problems, (ii) downstream side problems, (iii) supporting side problems.

\section{A. Upstream side problems}

Upstream side problems, include:

- Resource/exploration risk: There is lack of information about available reserves at the time of the auction process. It makes investors proposed higher price or not interested in the auction which causes the price of geothermal power becomes uneconomical. It also makes the project become unbankable since the risk is high and unpredictable so that investor distress in seeking financing.

- High investment on initial period: Geothermal business is an expensive business. It takes about US\$25 million in the initial exploration [16], and it surely succeeded yet. So if the initial exploration failed then the investor will loss about US\$25 million.

- Overlap with conservation/protected forest land: Around $41.6 \%$ of the geothermal potential is in the area of protected forests or conservation areas (Table VI) [10]. Whereas in the existing rule, geothermal development is not possible to be done in that area since geothermal is still regarded as the mining industry according to Geothermal Law, and based on the rules in the field of forestry, mining cannot be done in the protected forest or conservation areas.

$$
\text { TABLE VI }
$$

GeOthermal Potential AREA IN THE PRotected Forests oR CONSERVATION AREAS

\begin{tabular}{ccc}
\hline Forest Status & Amount & Potential (MW) \\
\hline Conservation Area & 29 & 3,428 \\
Protected Forest & 52 & 8,641 \\
\hline Total & $\mathbf{8 1}$ & $\mathbf{1 2 , 0 6 9}$
\end{tabular}

Source: Sukhyar and Danar, 2010

\section{B. Downstream side problems}

Downstream side problems, include:

- Less attractive geothermal electricity price: Before 2009 , the selling price of geothermal electricity is very not attractive and geothermal auction prices to get GWA usually not equal to the selling price of electricity from the developer to PLN. But since late 2009, the government set tariffs for geothermal electricity to be purchased by PLN. When it was applied, the Minister MEMR Decree no. 32/2009 and no. $2 / 2011$ set a maximum price of $\$ 9.7$ cents $/ \mathrm{kWh}$ and applies to the whole of Indonesia. According to the writer, this price is still not very attractive, especially for the eastern region of Indonesia or in remote areas. But then the government changed the rules by issuing Minister MEMR Decree no. 22/2012 which set the Feed in Tariff and set a fixed price that must be purchased by PLN. The price has been made for the different regions of Indonesia. But this rule is not fair for PLN as a buyer since there is no opportunity to negotiate the price.

- Single buyer: the structure of the geothermal market in Indonesia is a monopsony market, means market consist of many sellers and one buyer. This becomes a problem to the seller because it has a weak bargaining position [10].

\section{Supporting side problems}

Supporting side problems include:

- Complex bureaucracy system: Last doing business report released by World Bank put Indonesia in ranks 120 of 189 countries. Far behind Singapore (rank 1), Malaysia (rank 6), Vietnam (99), and even Philippines (108) [17]. This shows that Indonesia is not a comfortable place to doing business including geothermal business. This is due to complex bureaucracy system in Indonesia, too much business permits, corruption, as well as inconsistency rules and regulations. Especially in the field of geothermal, most of the authority has been delegated to the Local Government. Some local governments often "make difficult" the licensing process, has no geothermal expertise or reliable human resources so that make the process related to the geothermal development longer especially in the tender process.

- Lack of national commitment: In the past, both central government and local government are not too concerned about geothermal development. It is proved by the absence of a strong leadership/commitment, especially from the President and the Head of the Region to promote geothermal development.

- Lack of awareness among consumers and society about renewable (green) energy development.

\section{GEOTHERMAL ENERGy DEVEloPMENT PROSPECT}

The author will explore geothermal energy development prospect in Indonesia based on the problems above.

\section{A. Upstream side problems}

The government tries to reduce upstream side problems, which include resource exploration risk and high investment on initial period, with the geothermal fund. This fund already exist in 2011 but until now has not been used yet. The problem is the IIA as the agent/manager of this fund is too rigid in the disbursement of funds. Requirements requested by the IIA assessed by local government or IUP holders/PT PGE are too difficult, such as a borrower should provide a $100 \%$ collateral, and other conditions. It is required by the IIA in order to safeguard the principles of governance, but according PMK 03/2012, IIA actually 
already exercise its governance if they followed all the rules in the regulation, especially by involving international consultant to monitor every activity performed by the borrower when using geothermal fund. In addition, PMK $03 / 2012$ also mentioned that it is desirable if the IIA suffered losses during the management of geothermal fund has been complying with the regulation.

This should be addressed by the Government by asking IIA to soften the requirements as long as fulfilled the governance principle as it was arranged in PMK 03/2012. So that geothermal fund can actually be used to accelerate the development of geothermal energy exploration by reducing the exploration risk.

The government also try to overcome the problem of overlapping with conservation area and protected forest land by issuing the new Geothermal Law. The Law has just been verified by the parliament. In the new law, Geothermal is no longer classified as a mining venture so it is possible to use the forest with only the utilization of environmental services permit.

\section{B. Downstream side problems}

The most difficult problem in the downstream side is the selling price of geothermal electricity. This problem tries to solve by the government with the implementation of Feed In Tariff (FIT) since 2009. But as mentioned above, these rules changing all the time and unfair for the first developer since the newer rule always give higher price.

Minister MEMR Decree no. 22/2012 also set a fixed price that must be purchased by PLN, although the price is very attractive for the developer (around US\$11.5 cent - US\$18.5 cent $/ \mathrm{kWh}$ ) but according to the writer it is not fair for PLN, since PLN cannot negotiate the price.

However, in 2014, Minister MEMR issued a new rule about the selling price of geothermal electricity namely Minister MEMR Decree No. 17/2014, which revoke Minister MEMR Decree no. 22/2012. This rule set about the highest benchmark price of geothermal electricity, since this is only the benchmark then there is room for PLN to negotiate the price. The range of the price is US\$ 11.8 cent US $\$ 29.6$ cent $/ \mathrm{kWH}$ depend on the COD time and area. This price is higher than the price set before. According to the writer, this rule is fair enough for both side, developer of geothermal energy and PLN, since the developers have a chance to get high selling price, while PLN has a chance to negotiate the price. This rule also allows the first developers to renegotiate the selling price of electricity to PLN so that this rule is also fair for the first developer.

\section{Supporting side problems}

The problems on this side tried to be solved by the GoI through the new Geothermal Law. This Law regulated that the utilization of geothermal for power plant will be managed by the Central Government, of which previously submitted to the Local Government. With managed by the central government is expected the bureaucratic obstacles that have been happening in Local Government especially in the terms of licensing, the slow process of the auction, and the lack of reliable human resources can be addressed. Permitting process can be trimmed, tender process can be accelerated and the central government has the human resources who understand the intricacies of geothermal.

Right now, according to the author, National commitment for the development of geothermal energy is quite good. It is proved by the issuance of a new Geothermal Law which gives more supports for the development of geothermal especially for power plant/electricity. In addition, the incentives provided by the Government is also quite good in both the upstream and downstream sides, either tax incentives, incentives in the price of electricity, as well as incentives in financing exploration.

Finally, regarding the lack of awareness among consumers and society about renewable (green) energy development can be increased by the Government by providing a vigorous socialization and examples from the leaders.

\section{CONCLUSIONS}

Indonesia has the largest of geothermal potential in the world, and it is still very huge that can be utilized for energy development. Although, the current situation is still very far from the target but with the new geothermal law, regulations of Minister of MEMR about the selling prices, geothermal funds and other incentives given to the geothermal industry, I believe that in the next five years the development of geothermal industry for electricity would be encouraging. But not least important is a strong commitment from leaders to continue supporting geothermal development and public awareness of the importance of renewable (green) energy development.

\section{NOMENCLATURE}

$\begin{array}{ll}\text { FIT } & \text { Feed in Tariff } \\ \text { FTP } & \text { Fast Track Program } \\ \text { GWA } & \text { Geothermal Working Area } \\ \text { IUP } & \text { Geothermal Mining Permit } \\ \text { KMK } & \text { Minister of Finance Decree } \\ \text { MEMR } & \text { Minister of Energy and Mineral Resources } \\ \text { PMK } & \text { Minister of Finance Decree } \\ \text { PGE } & \text { PT Pertamina Geothermal Energy } \\ \text { PIP } & \text { Indonesia Investment Agency } \\ \text { PLN } & \text { PT Perusahaan Listrik Negara (Persero) } \\ \text { SJKU } & \text { Business Viability Guarantee Letter }\end{array}$

\section{REFERENCES}

[1] Perusahaan Listrik Negara, Rencana Usaha Penyediaan Tenaga Listrik PT PLN (Persero) 2013-2022, Jakarta: PT PLN (Persero), 2013.

[2] S. A. Damayanty, Kebijakan Ketenagalistrikan Indonesia, Jakarta: Naga Media, 2014.

[3] (2014) Okezone website. [Online]. Available: http://economy.okezone.com/read/2014/08/13/19/1023728/krisislistrik-jawa-bali-terjadi-lebih-cepat-di-2016.

[4] PPRF. Tim Monitoring, Laporan Monitoring Efektifitas Kebijakan Pemberian Dukungan Pemerintah Pada Proyek 10.000 MW Tahap I, Jakarta: Badan Kebijakan Fiskal, 2010.

[5] (2013) The World Bank website. [Online]. Available: http://data.worldbank.org/indicator/EG.USE.ELEC.KH.PC.

[6] Kementerian Koordinator Bidang Perekonomian and Kementerian Perencanaan Pembangunan Nasional/Badan Perencanaan Pembangunan Nasional RI, Masterplan Percepatan dan Perluasan Pembangunan Ekonomi Indonesia 2011-2025, Jakarta: Kementerian Koordinator Bidang Perekonomian, 2011. 
[7] Kementerian Energi dan Sumber Daya Mineral RI, Permen ESDM Nomor 21 Tahun 2013 tentang Daftar Proyek-Proyek Percepatan Pembangunan Pembangkit Tenaga Listrik yang Menggunakan Energi Terbarukan, Batubara dan Gas serta Transmisi Terkait, Jakarta: Kementerian ESDM, 2013.

[8] R. Remigius, "Economic Policies and Incentives to Expand the Geothermal Energy Industry in Indonesia," IIIEE thesis, Lund, Sweden, 2012.

[9] National Geothermal Assosiation of the Philippines. (2010) ngaphil website. [Online] Available: http://www.ngaphil.org/services.

[10] R. Sukhyar and A. Danar, Energi Panas Bumi di Indonesia: Kebijakan Pengembangan dan Keputusan Investasi, Bandung: Badan Geologi Kementerian ESDM RI, 2010.

[11] Republik Indonesia, "Undang Undang Nomor 27 Tahun 2003 tentang Panas Bumi," Jakarta: Republik Indonesia, 2003.

[12] R. Ibrahim, U. L. Simandjuntak. and Jarman. Indonesia Geothermal Development for Power Project. Jakarta, 2012.
[13] H. Setiawan and S. A. Damayanty, "Geothermal Fund: Solusi Percepatan Pembangunan PLTP," Info Risiko Fiskal, Jakarta: Pusat Pengelolaan Risiko Fiskal, 2012, Vol. 2.

[14] Kementerian Keuangan Republik Indonesia, Peraturan Menteri Keuangan Nomor 130/PMK.011/2011 tentang Pemberian Fasilitas Pembebasan atau Pengurangan Pajak Penghasilan Badan, Jakarta: Kementerian Keuangan Republik Indonesia, 2011.

[15] E. Nursurachman, Evolusi Proyek dan Penjaminan Pemerintah Pada Program Percepatan Pembangunan Pembangkit Listrik (Fast Track Program-FTP) 10.000 MW, Jakarta: Naga Media, 2014.

[16] PT Pranata Energy Nusantarta, Developing Contingent Liability Control System of Geothermal Projects, Jakarta : PT Pranata Energy Nusantara, 2011.

[17] World Bank, Doing Business 2014: Understanding Regulation for Small and Medium Size Enterprises, Washington: World Bank Group, 2013. 